
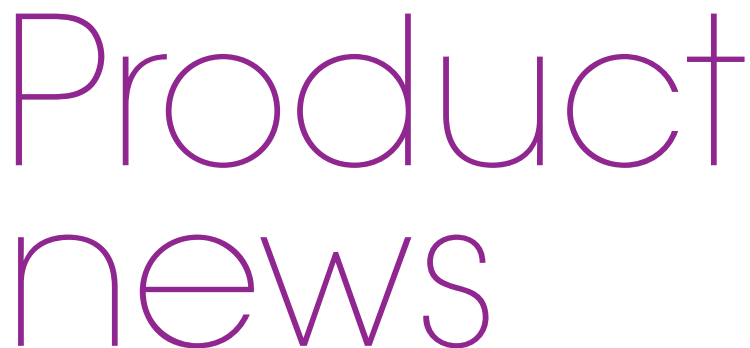

Product news is provided as a service to readers using text and images from

the manufacturer, supplier or distributor and does not imply endorsement

by BDJ Team. Normal and prudent research should be exercised before.

purchase or use of any product mentioned.

\title{
THE CASE FOR GOOD SUGARS
}

At the British Dental Conference and Dentistry Show 2018, Tim Ives will argue the case for good sugars in his Hygienist \& Therapist Symposium session 'Sweet offender versus sweet pretender: utilising sugars to treat and prevent disease'.

Tim (pictured) said: 'My presentation will look at when we started to eat lots more sugars and why, as well as how "good" sugars can be utilised in practice to prevent and treat oral disease. I will cover themes like government misinformation, bad science and ruthless marketing from the sugar industry.

'I will also look at how sugar alcohols

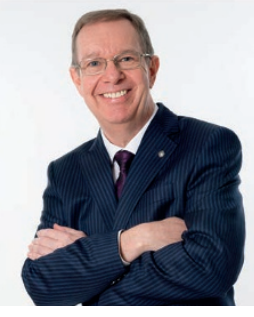

the bacteria

that cause

decay. It's a cheap and simple way to prevent oral disease and also build up your appointments book by offering additional treatments.

The British Dental Conference and Dentistry Show 2018 will take place on Friday 18 and Saturday 19 May at the NEC in Birmingham, co-located with DTS.

For further details visit www. thedentistryshow.co.uk or www.bda.org/ conference, call 02073485270 or email dentistry@closerstillmedia.com.

\section{EXPLORE THE LINKS BETWEEN DENTAL AND SYSTEMIC HEALTH}

It is often said that the mouth is the gateway to the body and the links between oral health and systemic health support this.

Melonie Prebble (pictured, left) and Victoria Wilson (pictured, right) will be exploring this topic in the Hygienist \& Therapist Symposium at the British Dental Conference and Dentistry Show this May.

They said: 'The dental practice is a good platform from which to discuss and potentially prevent both oral and systemic diseases. This is an exciting time to explore this topic and how it can contribute to our patient care.
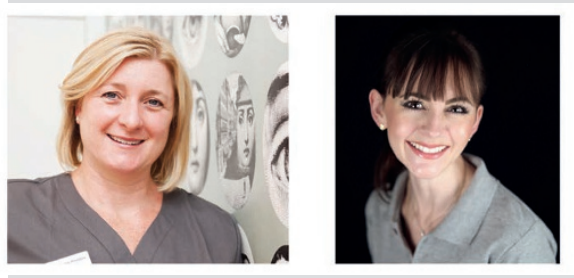

'We will be covering the subject as broadly as possible. Delegates will certainly take home a good overview of the current thinking on this subject. We hope to give them more confidence and improve their verbal skills to impart their new knowledge. Dental hygienists and dental therapists attending should feel empowered and motivated to apply this within the clinical setting.'

Melonie and Victoria will join an inspiring speaker line-up including Iain Chapple, Marina Harris, Elaine Tilling, Deborah Lyle, Ben Atkins, Tim Ives, Fiona Ellwood and Chris Barrow.

To make sure you don't miss out, register for your free pass online today.

For further details visit www. thedentistryshow.co.uk or www.bda.org/ conference, call 02073485270 or email dentistry@closerstillmedia.com.

\section{DENTAL NURSES AND DENTAL PHOTOGRAPHY}

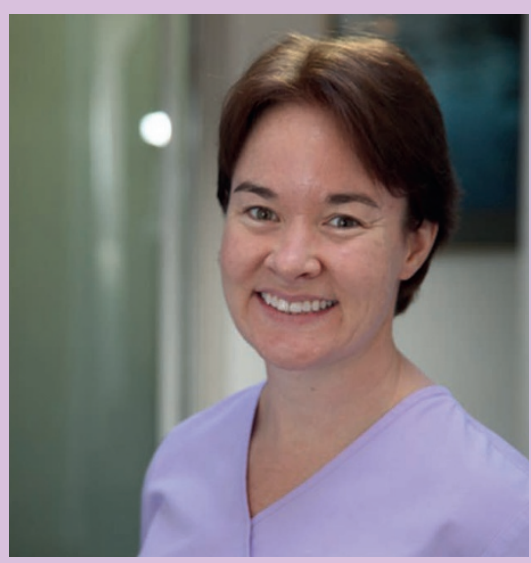

Discover the benefits of dental photography for dental nurses at the British Dental Conference and Dentistry Show 2018.

Diane Rochford will be discussing the topic in the Dental Nurses Forum. She said: 'By developing photography skills, the dental nurse can become more directly involved in treatment procedures, as well as more involved with patients. They also have the opportunity to take on more responsibilities, advance their knowledge and skills, and feel more valued as a team member by the clinicians and the patients. Perhaps most importantly, patient care is also improved.

'I hope delegates will gain some insight into the importance of taking dental photographs and learn how beneficial dental photography is in the practice today.'

The British Dental Conference and Dentistry Show 2018 will take place on Friday 18 and Saturday 19 May at the NEC in Birmingham, co-located with DTS.

For further details visit www. thedentistryshow.co.uk or www.bda.org/ conference, call 02073485270 or email dentistry@closerstillmedia.com. 